\title{
O DIREITO DE CRIANÇAS À VISITAÇÃO A FAMILIARES EM RESTRIÇÃO DE LIBERDADE E A GESTÃO DECISÓRIA NO DISTRITO FEDERAL: UMA REVISÃO NORMATIVA
}

\author{
CHILDREN'S RIGHT TO VISIT THEIR FAMILIES IN PRISON AND DECISION-MAKING \\ MANAGEMENT IN BRAZILIAN FEDERAL DISTRICT: A NORMATIVE REVIEW
}

\section{Carolina Costa Ferreira}

Doutora em Direito, Estado e Constituição (UnB), Líder do Grupo de Pesquisa "Criminologia do Enfrentamento", Professora do PPGD em Direito Constitucional do Instituto Brasileiro de Ensino, Desenvolvimento e Pesquisa (IDP), Professora de Criminologia, Direito Penal e Processual Penal (CEUB).

\section{Eduarda Toscani Gindri}

Doutoranda e Mestra em Direito pelo Programa de Pós-Graduação em Direito da Universidade de Brasília, na linha de pesquisa "Sociedade, conflito e movimentos sociais". Bacharel em Comunicação Social - Jornalismo pela Universidade Federal de Santa Maria, com período de estudos na Universidade do Algarve, em Portugal.

\section{Resumo}

O artigo discute o direito das crianças à visitação de familiares em privação de liberdade no Distrito Federal, enquadrando o ato de visitar como procedimento da execução penal e como circunstância de violação a direitos fundamentais. A pesquisa investiga limites legais e institucionais do direito de visitação na execução penal, utilizando a análise documental como metodologia. Para isto, o texto discute o sentido de prioridade absoluta dado à proteção à criança e ao adolescente, pela Constituição Federal, correlacionando-o a competências administrativas, legislativas e decisórias sobre o direito de visita, no âmbito da execução penal. Apresentam-se, na segunda seção, dados sobre a execução penal no Brasil, que indicam a invisibilidade sobre a infância que transita pelo cárcere, em uma tentativa de "sanitarização" da discussão, reduzida à informação sobre a existência ou não de estruturas de visitação no cárcere. O terceiro tópico levanta discussões empíricas, discutindo o conceito de família, a titularidade do direito à visita e a (in)compatibilidade de tal direito a medidas de privação de liberdade. A quarta seção é dedicada à regulação da visita social no Distrito Federal, indicando a revisão normativa correspondente, suas práticas e limites 
institucionais, apontando dois casos em que se verificam a atuação do Poder Judiciário. $O$ artigo dialoga com a análise qualitativa das normas e a produção teórica em execução penal, com especial orientação à defesa de direitos fundamentais. Por fim, o texto indica uma agenda de pesquisa em torno do tema, que deve ser objeto de trabalhos futuros.

Palavras-chave: Proteção à Primeira Infância. Privação de liberdade. Direito de visita.

\begin{abstract}
The theme of this paper is the right of children to visit family members who are in prison in Brazilian Federal District. The research sought to carry out a mapping of the norms that deal with the right of children to visitation, focusing on its legal and institutional limits through documental analysis. For that, in the first topic, the organization of administrative, legislative and decision-making powers on visiting rights are described. In the second topic, the text articulates the visit as a right in the norms, recent changes and their foundations, based on data about prisons in Brazil. The third topic presents an empirical discussion about visitation in prison and the regulatory context of the Federal District analyzed. The last section is dedicated to the regulation of social visits in the Federal District. It was identified the existence of conflicts of rights in the decision on visitation, opposing the full protection of the child as a basis contrary to the visit and the right to family life and the re-socialization of the inmate as a favorable basis. The paper starts a dialogue between legislation and theory, particularly Fundamental Rights section. Finally, we present a list of research gaps on the topic that were not yet been explored.

Keywords: Protection of First Childhood. Freedom deprivation. Prison visiting.
\end{abstract}

\title{
1. CONSIDERAÇÕES INICIAIS
}

Descrever um imaginário sobre o "visitar" pode consistir em um processo de comunicação que envolve o ingresso de um sujeito (ou um conjunto de sujeitos) no espaço físico de outro - seja ele morada permanente ou transitória, que também carrega o sentido de "permanência". Descrever o ato de visitar como procedimento jurídico, por sua vez, pode excluir a subjetividade afetiva que a visita contorna, para, então, "racionalmente", construir e descrever um conjunto de procedimentos e fundamentos para que um sujeito ingresse no espaço físico do outro. Neste texto, descrever $\mathrm{o}$ ato de visitar será uma tarefa para compreender a organização normativa do Estado sobre o evento da visitação de crianças ao cárcere no Distrito Federal, a fim de refletir sobre a visita enquanto direito e mapear algumas das disputas que se articulam em torno da sua efetivação. A pergunta de pesquisa que se delineia, nesta fase de análise, com a seguinte formulação: quais são os limites institucionais e legais

Revista de Direitos Fundamentais \& Democracia, Curitiba, v. 26, n. 1, p. 87-118, jan./abr. 2021. 
ao direito de visitação de crianças a seus familiares presos no Distrito Federal? Em que medida embaraços institucionais podem - ou não - violar direitos assegurados à criança e ao adolescente?

Para responder à pergunta de pesquisa, realizamos pesquisa documental, considerando leis, portarias, cartilhas e outros produtos do Estado, em especial os de visitação a pessoas privadas de liberdade do Distrito Federal (DF). A escolha sobre a Unidade da Federação para este trabalho ocorreu em razão de esta possuir três tipos de unidades penitenciárias distintas: presídio feminino (em uma unidade mista, que detém uma ala de tratamento psiquiátrico para homens e mulheres), presídio masculino, ambos sob a tutela da Secretaria de Administração Penitenciária do Distrito Federal, e um estabelecimento prisional federal, sob a tutela do Departamento Penitenciário Federal, órgão do Ministério da Justiça e da Segurança Pública. Além disso, o Distrito Federal é a única dentre todas as Unidades da Federação incluídas na pesquisa $^{1}$ que disponibiliza extenso conjunto de documentos sobre a gestão das visitas em formato digital e acessível ao público.

No primeiro tópico, analisamos a Lei de Execução Penal, indagando quem são os sujeitos e instituições que organizam a produção normativa sobre o direito à visita e quais as representações socais presentes na Lei sobre o ato de visitar. Em seguida, abordamos o "visitar" enquanto direito, apontando os documentos normativos que garantem essa possiblidade e a principal modificação no direito de visita, com o Projeto de Lei da Câmara dos Deputados n 2.785, de 2011 (BRASIL, 2011), que gerou a aprovação da Lei no 12.962, de 8 de abril de 2014 (BRASIL, 2014). Por fim, analisamos com detalhamento todas as normativas oficiais que incidem sobre a gestão do direito de visita na execução penal do Distrito Federal, bem como cartilhas, informativos e julgados que revelam indícios de disputas e novas possibilidades de análise sobre o direito das crianças à visita no cárcere. No último tópico, indicamos os desafios de uma agenda de pesquisa que defenda a proteção à criança e ao adolescente como prioridade absoluta do Estado, como nos indica a Constituição Federal, no sentido de se efetivar sua proteção integral, ainda em meio a um cenário de reprodução de punitividades administrativas e judiciais, como é a execução penal no Brasil.

\footnotetext{
1 Este artigo apresenta resultados complementares da pesquisa "Crianças e o cárcere: efeitos do sistema prisional no desenvolvimento da primeira infância", realizada pelo Observatório de Direitos Humanos do Instituto Brasileiro de Ensino, Desenvolvimento e Pesquisa (IDP), com financiamento da Organização dos Estados Ibero-americanos para a Educação, a Ciência e a Cultura (OEI - Brasil).

Revista de Direitos Fundamentais \& Democracia, Curitiba, v. 26, n. 1, p. 87-118, jan./abr. 2021.
} 


\section{ORGANIZAÇÃO E DIMENSÃO DO VISITAR: INSTITUIÇÕES, SUJEITOS E NÚMEROS DA DINÂMICA}

A execução penal é o momento em que o tempo de liberdade de ir e vir, de permanecer com os sujeitos do seu convívio nos locais e atividades que deseja é retirado pela ação do Estado em manter, de forma um tanto definitiva, uma pessoa no cárcere. As "estadas" no cárcere são reguladas, em grande parte, pela Lei de Execução Penal (LEP - Lei $n^{\circ}$ 7.210/1984), referência sobre a organização da administração pública em torno do aprisionamento. Segundo a LEP, há oito órgãos do Estado brasileiro considerados parte da "execução penal", para os quais a lei prescreve um conjunto de atribuições. Os órgãos do Poder Executivo vinculados ao Ministério da Justiça são o Conselho Nacional de Política Criminal e Penitenciária (CNPCP) e o Departamento Penitenciário Nacional (DEPEN).

O DEPEN é responsável pela execução, avaliação e monitoramento da política penitenciária nacional, pela coordenação específica dos estabelecimentos penais federais e pela assistência dos serviços penais em todo o país. As penitenciárias federais são estabelecimentos de segurança máxima e abrigam pessoas que desempenham funções de liderança em organizações criminosas, praticaram crimes que os coloquem em risco nas unidades comuns ou são "réus colaboradores". Segundo o Ministério da Justiça e Segurança Pública, cada unidade possui 208 celas individuais e são presídios com taxa de ocupação abaixo da média - da superlotação geral de $159,62 \%$ (BRASIL, 2020), os presídios federais têm $59 \%$ de lotação. O Regime Disciplinar Diferenciado (RDD) também se aplica aos presídios federais, porém de forma mais dura do que o previsto no art. 52 da LEP, com a suspensão total das visitas e dos banhos de sol coletivo, o cumprimento em uma das doze celas específicas para o RDD com um "solário", espaço aberto na própria cela para o banho de sol (BRASIL, 2020).

As Unidades da Federação podem ainda criar departamentos penitenciários locais ou órgãos similares (secretarias de administração prisional ou penitenciária, institutos de administração penitenciária), estabelecendo como atribuição destes órgãos supervisionar e coordenar os estabelecimentos locais estaduais. Vinculados ao Poder Judiciário, há três órgãos com atribuições de interferência nos processos e fiscalização dos estabelecimentos prisionais: o Juízo da Execução, representado por 
um magistrado indicado para as "varas de execução penal", que irá gerir tempos e formas de cumprimento das sentenças, unificar penas, progredir ou regredir o cumprimento de penas, aplicar suspensão condicional ou o livramento condicional, declarar extinções de punibilidade e realizar inspeções periódicas. Ademais, integram a execução penal o Ministério Público e a Defensoria Pública, com atribuições de fiscalização e de atuação nos processos penais individuais e coletivos. Há Núcleos Especializados das Defensorias Públicas para atuação na execução penal, agindo mais estrategicamente em questões coletivas, a fim de se estabelecer parâmetros mínimos de cumprimento de penas em alinhamento aos direitos fundamentais (FERREIRA, 2019), ainda que reconhecida a superlotação carcerária no Brasil e as péssimas condições de cumprimento das penas nos mais diversos regimes, em situação que o Supremo Tribunal Federal já denominou de "Estado de Coisas Inconstitucional" (BRASIL, 2015).

Além disso, também se deve destacar a existência do Conselho Penitenciário, órgão consultivo e fiscalizador da execução da pena, composto por membros e membras de atuação correlata à área penal, com mandato de 4 anos, os quais supervisionam, inspecionam e avaliam os estabelecimentos, emitem parecer sobre indulto, dentre outras atribuições definidas nos artigos 69 e 70 da Lei de Execução Penal (BRASIL, 1984). Os Patronatos, entidades públicas ou privadas para assistência de albergados ou egressos, podem auxiliar na fase de transição entre o final do cumprimento da pena e a ostentação da difícil situação de "egresso" do sistema prisional, em que não há políticas públicas especificamente voltadas a este universo de pessoas.

O Conselho da Comunidade, em cada comarca, composto por um representante de associação comercial ou industrial, um advogado indicado pela Seção da Ordem dos Advogados do Brasil, um Defensor Público indicado pelo Defensor Público Geral e um assistente social escolhido pelo Conselho Nacional de Assistentes Sociais, segundo os artigos 80 e 81 da LEP. No Distrito Federal, o Conselho da Comunidade teve sua primeira composição instituída em 2016 (TJDFT, 2016).

Em nenhuma dessas competências está explícita elaboração de diretrizes sobre visitação, embora a regulação sobre o ato de visitar o cárcere é - ou deveria ser - produto da interação desses órgãos. O DEPEN organiza diretrizes relacionadas aos presídios federais e traça alguns esforços de uniformização das práticas da gestão 
penitenciária em âmbito nacional. Contudo, do total de 1.507 estabelecimentos penitenciários do Brasil, dos quais 364 são presídios, apenas 5 estão vinculados ao Departamento Penitenciário Nacional (BRASIL, 2019c, p. 18-19). Os demais são competência das administrações públicas estaduais e gerenciados por normas produzidas pelos Juízos da Execução ou pelos Departamentos Penitenciários locais. Todas essas normas ainda são efetivadas nas práticas cotidianas impostas, como requisitos de vestimenta, proibição de objetos, fatos como feriados ou sanções que possam suspender as visitações, dentre outras mais diversas razões. Ou seja, por mais que as diretrizes nacionais sirvam como documentos de referência, não há uniformidade sobre as exigências normativas para a visita ou uma padronização em nível nacional dos procedimentos.

Quaisquer atos, no âmbito da execução penal, precisam ter previsão legal, a fim de que se possa assegurar tratamento isonômico e justo a todas as pessoas que cumpram pena no Brasil (ROIG, 2011). Regras gerais sobre direitos da pessoa presa e os deveres do Estado como mantenedor e executor das penas estão dispostos nos artigos 10 a 43 da LEP, em atendimento a comandos constitucionais que indicam o respeito à integridade física e moral das pessoas presas, o direito de permanência de mulheres presas, com seus filhos, durante o período da amamentação; dentre outros igualmente importantes ${ }^{2}$.Além disso, a hipótese de competência concorrente para legislar sobre normas de direito penitenciário, definida pela Constituição, em seu artigo 24, inciso I, pode criar assimetrias nos sistemas normativos entre União e Estados e entre Estados, entre si, o que pode dificultar a compreensão e a interpretação sobre diferentes normas que possam versar sobre os mesmos assuntos.

Se o campo da legalidade é relativamente bem definido na execução - ainda que com lacunas e contradições-, igualmente bem desenvolvida é a discricionariedade: considerando-se que os deveres disciplinares da administração penitenciária, em defesa da disciplina, "espaços de não-direito" se propagam na execução penal, por meio da tradução disciplinar de conceitos como "bom comportamento carcerário" ou a falta de clareza em torno do alcance das sanções disciplinares $^{3}$ (PAVARINI; GIAMBERARDINO, 2011, p. 337; SHIMIZU, 2019, p. 27).

\footnotetext{
2 Podem ser citadoscomo balizas de tal atuação, o art. $5^{\circ}$, incisos III, XXXVII, XXXIX, XLI, XLV, XLVII, XLVIII, XLIX, L, LIII, LIV e LV da Constituição Federal (BRASIL, 1988).

${ }^{3}$ Sobre este assunto, há a necessidade de se compreender o universo das sanções disciplinares no campo da execução penal como um "programa jurídico sancionatório", composto por "arranjos normativos que se formam no interior de diferentes áreas do direito e que estabelecem, ao menos, normas de comportamento (proibições), normas de sanção (as consequências) e normas de processo Revista de Direitos Fundamentais \& Democracia, Curitiba, v. 26, n. 1, p. 87-118, jan./abr. 2021.
} 
Além de organizar a administração pública em torno do cárcere, a Lei de Execução Penal representa um "dever-ser" sobre a vida dos sujeitos, assim como um imaginário sobre sujeitos dentro e fora do cárcere. Nesse imaginário, o visitar pode ser um evento para os órgãos do poder ou dos sujeitos de fora. Como visitar dos órgãos do poder, a Lei descreve a obrigação dos órgãos de fiscalização em entrar no cárcere, fiscalizar, relatar ou legitimar o cenário percebido na prisão. A redação legal sobre as visitas dos órgãos da Execução Penal é prescritiva ao ponto de estabelecer uma frequência mínima e a obrigação de registro dessas visitas.

O tempo da execução penal é quantificável em uma sentença baseada no tipo e nas condições de um comportamento cometido anteriormente, definida em anos e dias, passível de mutações entre níveis de afastamento e restrição ao cárcere ou na mudança do tempo para obrigações de ações e quantias monetárias. Apesar da suposta existência de uma sentença que pode ser questionada em todos os possíveis momentos em que o processo penal admite recurso, a realidade carcerária brasileira não é de um universo de certeza de tempo, ou mesmo de condenação 4 .

A coleta e divulgação de dados sobre a população carcerária e suas singularidades é uma inconstância no Brasil. No início de 2020, o Levantamento Nacional de Informações Penitenciárias (InfoPen), mantido pelo DEPEN, foi atualizado com dados referentes a julho de 2019, depois de quase quatro anos sem atualização. Em 2019, o InfoPen relatou 758.767 pessoas presas no Brasil, dos quais 253.963 ou seja, 33,47\%, ainda não possuíam condenação (BRASIL, 2020). São os chamados presos provisórios, que aguardam decisões no processo e o quantum de pena a cumprir, já na prisão.

O problema na insegurança sobre os dados coletados sobre a população carcerária foi objeto de atenção da gestão do Conselho Nacional de Justiça entre 2016 e 2018, que implementou o Banco Nacional de Monitoramento de Prisões (BNMP), instrumento, segundo o próprio $\mathrm{CNJ}$, que permitirá "identificar em tempo real e de

(quem e como pode afirmar que a proibição foi violada e impor uma consequência)" (MACHADO; PINTO, 2019, p. 120). Essa definição mais universal é importante para que a jurisprudência ultrapasse limites sobre, por exemplo, a necessidade de presença da Defensoria na atuação de processos disciplinares na execução penal e se volte a uma questão mais ampla: o uso das sanções disciplinares como prolongamento do encarceramento.

${ }^{4}$ Segundo o relatório de gestão de 2018, produzido a partir dos chamados "mutirões carcerários", o Conselho Nacional de Justiça (CNJ) constatou que "os "mutirões trouxeram à tona o descompasso e a assimetria da jurisdição de execução penal em todo o Brasil. Os mutirões também expuseram o sucateamento como foram encontradas as Varas de Execução Penal e, diante dessa perspectiva, acabou desnudando uma das causas mais significativas para a frustração do sentido e escopo da LEP, sem, no entanto, oferecer-Ihe adequada solução" (BRASIL, 2017b, p. 19).

Revista de Direitos Fundamentais \& Democracia, Curitiba, v. 26, n. 1, p. 87-118, jan./abr. 2021. 
forma individualizada as pessoas privadas de liberdade, procuradas e foragidas, a partir da listagem nominal e identificação única, com atribuição de um número de Registro Judiciário Individual” (BRASIL, 2018, p. 18). Em fevereiro de 2020, o BNMP marcava 865.622 pessoas presas, dos quais 370.894 (42,84\%) ocupam a condição de provisórios e 195.339 (22,56\%) estão em execução provisória - ou seja, ainda não há trânsito em julgado da sentença penal condenatória (BRASIL, 2020).

A questão da provisoriedade e da lacuna de informações precisa nos acompanhar para entendermos a organização do visitar no cárcere, especialmente nas dinâmicas relacionadas às crianças. Inicialmente, dentre o conjunto de críticas tratadas no âmbito jurídico sobre o excesso de provisoriedade na gestão dos inquéritos e processos penais brasileiros, pouco se fala na significativa ruptura familiar entre criança, genitores e cuidadores, provocada sem a existência de sentença. $O$ aprisionamento é, por si só, uma grave ruptura nas relações comunitárias, familiares e de afeto dos sujeitos, com impactos em diferentes ramificações das suas vidas: na comunicação, na custódia das crianças, no cuidado de idosos, na manutenção econômica das famílias.

A lacuna de informações reforça um cenário de incerteza para a elaboração de políticas públicas, o que se agrava quando procuramos, nos relatórios oficiais, informações detalhadas sobre a visitação. No Levantamento de Informações Penitenciárias divulgado sobre a situação prisional das mulheres no Brasil de 2019, referente aos dados de 2017 ("InfoPen Mulheres"), 46,53\% dos estabelecimentos relataram não ter local para visitação em suas dependências. Para as unidades mistas, esse dado diminui para $23,93 \%$ de estabelecimentos que possuem estrutura para a visitação de familiares e de amigos de mulheres encarceradas. No Distrito Federal, segundo o InfoPen, 100\% das Unidades Mistas possuem dependências adequadas para a visitação de familiares encarceradas (BRASIL, 2019, p. 19). No caso dos estabelecimentos penitenciários voltados à população masculina, apenas o InfoPen de 2014 dispõe de tal informação, indicando que 63\% das unidades prisionais relataram não ter local para visitação em suas dependências (BRASIL, 2014, p. 88). Esse mesmo documento, quando apresenta informações sobre filhos, ressalta que esse dado foi informado para apenas 3,34\% do universo do relatório, do qual $41 \%$ não possui filhos, $22 \%$ possui 1 filho, $17 \%$ possui dois, e $20 \%$, três ou mais filhos (BRASIL, 2015, p. 6364). O relatório não discriminou os dados segundo o gênero e o relatório de 2014 , embora afirme que a maioria das mulheres possui filhos, não traz esse dado concreto 
(BRASIL, 2014, p. 88). O relatório de 2017 conseguiu ampliar a coleta de informações sobre filiação para $9 \%$ do universo abordado, separando os dados por gênero. Entre os homens, $53 \%$ declararam não ter filhos, $21 \%$ possuíam um filho; $14 \%$ informaram ter 2 filhos e $12 \%$ possuíam três filhos ou mais. Por outro lado, o relatório não apresenta informações sobre condições ou frequências de visita (BRASIL, 2019, p. 42-43).

No relatório InfoPen Mulheres de 2019, foi divulgada, também, a informação em relação aos homens: dentre estes, $47,2 \%$ possuem um filho, $27 \%$ possuem dois filhos e 12,3\% possuem três filhos (BRASIL, 2019, p. 43-44). Entre as mulheres, $28.9 \%$ informaram que possuem um filho, $28,7 \%$ dois filhos e $21,7 \%$ três filhos (BRASIL, 2019, p. 43-44). O relatório não informa, todavia, a porcentagem da população carcerária representada por estes dados. Já a coleta de dados sobre visitação, nos relatórios recentes, trouxe mais informações: o Relatório de 2019informa que, nos estabelecimentos masculinos, a média de visitas é, em média, de 4,55 visitas por preso a cada semestre; em unidades femininas, foram 4,45 visitas semestrais, em média; esse número é bem menor em unidades mistas $-2,63$ por pessoa presa. Segundo os dados do mesmo relatório, a unidade mista do Distrito Federal, onde fica a Penitenciária Feminina do DF, recebeu, em média, 5,24 visitas por semestre (BRASIL, 2019, p. 19).

Na série dos últimos cinco anos, poucos dados oficiais foram produzidos sobre a condição de paternidade, maternidade e potencial de trânsito de crianças pelo cárcere. $\mathrm{O}$ número de crianças brasileiras impactadas pelo aprisionamento $\mathrm{e}$ as características deste impacto é uma informação sem precisão e direcionamento, embora, diante da magnitude dos dados de aprisionamento à disposição no Brasil, certamente não é irrelevante. Levando em conta as ainda precárias informações descritas acima, se mantemos 850 mil pessoas, em média, no cárcere ${ }^{5}$, e pelo menos $13,5 \%$ dos homens (maioria dos presos) são pais, estamos falando, pelo menos, de 114.750 famílias afetadas pelo cárcere. Levando em conta que são famílias predominantemente negras - 35\% declaram-se brancos, $46,27 \%$ pardos e $17,37 \%$ pretos (BRASIL, 2019, p. 31-32), de baixa escolaridade $-51,35 \%$ sequer completaram o ensino fundamental (BRASIL, 2019, p. 34-35), são famílias para as quais a relação com o cárcere é mais um adendo no contexto de vulnerabilizações provocadas pela

\footnotetext{
5 É importante ter em mente que qualquer dado sobre o sistema carcerário representa uma "fotografia" das possíveis movimentações que possam ter ocorrido no dia da coleta dos dados que, posteriormente, foram compilados. Não temos um sistema informatizado que acompanhe, em tempo real, entradas e saídas dos mais de 1.700 estabelecimentos prisionais no Brasil, de modo que o que temos são estimativas de uma fotografia pouco nítida.

Revista de Direitos Fundamentais \& Democracia, Curitiba, v. 26, n. 1, p. 87-118, jan./abr. 2021.
} 
conduta do Estado, presente ou ausente, em seu cotidiano racializado.

Além da ausência de dados sobre os processos de visitação, a Lei de Execução Penal é omissa no que se refere ao tema da visitação. Em 2014, o Ministério da Justiça publicou o "Modelo de Gestão para a Política Prisional", que reconhece a pluralidade de agentes que transitam pelo cárcere, entre profissionais, pessoas em privação de liberdade e seus familiares, mas tal documento ainda não é assertivo em estabelecer balizas sobre os procedimentos de visita:

\begin{abstract}
Nota-se claramente que muito embora a "família" esteja presente nos mais variados discursos acerca da "reintegração social" das pessoas privadas de liberdade, sendo o trabalho de aproximação ou a retomada do vínculo familiar a principal resposta de assistentes sociais quando, durante as visitas realizadas pela consultoria, foram questionados sobre suas principais funções, os estabelecimentos prisionais, em sua maioria, sequer possuem espaços adequados para receber as visitas sociais e íntimas, de modo que também esta atribuição do serviço social penitenciário fica prejudicado (MELO; DAUFEMBACK, 2016, p. 137).
\end{abstract}

As visitas das redes de afeto são quase "não organizadas" pela LEP, que apenas prescreve que a penitenciária "dos homens" deve ser construída em local que não restrinja a visitação (art. 90 da LEP). Esta estranha expressão - "penitenciária dos homens" - explicita um traço da organização normativa da Lei de Execução Penal, do cenário das políticas penitenciárias e do estado da arte sobre prisão: a penitenciária das mulheres há pouco tempo foi encontrada como problema social e há muito tempo é uma construção paralela, mas dependente das projeções da penitenciária dos homens.

Essa constatação se reforça em razão de um imaginário normativo sobre as relações de afeto de pessoas privadas de liberdade, que se organiza para dinâmicas entre homens presos e mulheres que os aguardam do lado de fora. As únicas remissões à palavra "mulher" originais no texto de 1984 falam da exigência, sem qualquer parâmetro de definição, de "ensino profissional adequado à sua condição" para a mulher condenada e da exigência de corpo de funcionários do sexo feminino no estabelecimento destinado para mulheres. A figura feminina representada no texto original da LEP e ainda não alterada é a figura da companheira. Como direito da pessoa em privação de liberdade está a visita do "cônjuge" e da "companheira", ou a saída temporária em caso de falecimento ou doença grave dessas pessoas (art. 120 da LEP).

$\mathrm{Na}$ medida em que o problema do encarceramento feminino se tornou um ponto da agenda legislativa e político-criminal, o texto recebeu um conjunto de modificações. Em 1997, a Lei de Execução Penal, no art. 82, recebeu a redação Revista de Direitos Fundamentais \& Democracia, Curitiba, v. 26, n. 1, p. 87-118, jan./abr. 2021. 
determinando que "a mulher e o maior de sessenta anos, separadamente, serão recolhidos a estabelecimento próprio e adequado à sua condição pessoal". Em 2009, são incluídas modificações, por meio da Lei n 11.942, que definem condições mínimas para que os presídios mantivessem mulheres gestantes ou puérperas, com bebês de seis meses de idade a crianças de até sete anos de idade ${ }^{6}$. Dentre as modificações, a lei aprovada estabeleceu que as prisões possuíssem atendimento médico às gestantes

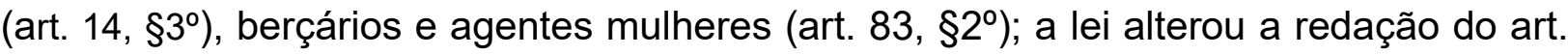
89, que previa um "poderá" para a existência de creche e seção de gestantes, para um "será", prescritivo de obrigação, seguido de requisitos mínimos para tais setores. Em 2018, a Lei n 13.769 alterou a Lei de Execução Penal novamente, apresentando as exigências de monitoramento pelo DEPENe requisitos diferenciados para a progressão de regime para mulheres mães ou responsáveis por pessoas com deficiência (arts. 72 e $112, \S 3^{\circ}$, ambos da LEP).

São essas modificações que também incluem a palavra "criança" na Lei, até então incluída na categoria "descendente", que está no rol de direito de visita das pessoas presas. Não há qualquer referência semântica à infância no cárcere até o reconhecimento da maternidade privada de liberdade, ainda que mães, pais, familiares, gestantes e crianças sempre tenham habitado ou transitado pelo cárcere. A alteração do texto, bem como outros eventos relacionados ao tema, são produto de um processo de construção de agenda que atravessa diferentes formas de comunicação acadêmica, jurídica, institucional ou até jornalística - sobre o tema da maternidade no cárcere.

A demografia do cárcere brasileiro não apresenta um olhar sobre o que é o trânsito da infância pelo espaço da prisão. Do delineado até aqui, há possibilidades de solidificar a hipótese de que o ingresso de crianças no cárcere - esse visitar diverso do nascer e do crescer junto da mãe - parece uma "não questão", ou um "não problema", invisível, que atua em uma espiral do silêncio a partir da centralidade sobre a questão da maternidade no cárcere. A existência da criança vinculada à mãe e o silenciamento do tema das visitações em normativas e políticas públicas também é problematizado, nos Estados Unidos, por Chesa Boudin. O status quo do direito à visitação é "sanitarizado" das necessidades e interesses das crianças, ao mesmo tempo em que

\footnotetext{
${ }^{6}$ Os debates entre parlamentares sobre a aprovação da lei levaram em consideração a necessidade de o Estado prover às mulheres mães o direito de permanecerem com seus filhos durante o período da amamentação, como indica a Constituição Federal, mas também houve discussão sobre se o ambiente do cárcere seria o mais adequado ao exercício da maternidade. (BRASIL, 2009, p. 64.388-64.389).

Revista de Direitos Fundamentais \& Democracia, Curitiba, v. 26, n. 1, p. 87-118, jan./abr. 2021.
} 
"o foco das mães parece que reflete a afirmação, na maioria do mundo, que a prática do encarceramento das mães é geralmente mais disruptiva para as vidas das crianças que o aprisionamento dos pais" (BOUDIN, 2011, p. 86).

No caso brasileiro, a revisão de literatura sobre encarceramento de mulheres indica muito mais a incidência de questões estruturais, como a arquitetura dos presídios, voltados a homens, ou as estratégias de criminalização secundária de mulheres em razão da Lei de Drogas (TEIXEIRA; OLIVEIRA, 2016), invisibilizando, também, o cuidado com crianças em visitas.

Assim, a própria "positivação" do direito de visita das crianças aos genitores em privação de liberdade é acionada legislativamente pela proteção à maternidade. Em 2014, o campo jurídico modifica o espaço de disputas "oficiais" sobre o direito de visita das crianças, que, embora compreensível do texto legal, não era produto de uma definição normativa explícita. Até este ano, o direito era argumentado a partir de dispositivos que expressavam garantias fundamentais e asseguravam direitos mais amplos, manejados pelas práticas administrativas de cada estabelecimento prisional, pelas varas de execução locais e, eventualmente, pelos Tribunais.

\section{VISITAR COMO "DIREITO": ESPAÇOS INSTITUCIONAIS PARA UMA DISPUTA}

A convivência familiar e comunitária é direito resguardado às crianças e aos adolescentes no art. 227, da Constituição Federal, também previsto no $\operatorname{art}^{\circ}$ da Lei $n^{\circ}$ 8.069, de 13 de julho de 1990 (Estatuto da Criança e do Adolescente). A proteção integral a crianças e adolescentes é decorrente do cumprimento, pelo Brasil, de compromissos internacionais que contemplam questões interseccionais na proteção a direitos humanos, como a igualdade racial (LIMA; VERONESE, 2010). Além disso, a visitação é direito da pessoa em privação de liberdade, o que possibilita as visitas dos cônjuges, companheiras e companheiros, parentes e pessoas da sua rede de afeto ${ }^{7}$. Neste tópico, buscamos a construção discursiva produzida pelo campo jurídico internacional e nacional sobre a visitação, tendo em vista esses dois polos de direitos:

\footnotetext{
${ }^{7}$ A Regra 37 das Regras de Mandela dispõe que "os seguintes itens devem sempre ser pendentes de autorização por lei ou por regulamento da autoridade administrativa competente: [...] d) Qualquer forma de separação involuntária da população prisional geral, como o confinamento solitário, o isolamento, a segregação, as unidades de cuidado especial ou alojamentos restritos, seja por razão de sanção disciplinar ou para a manutenção da ordem e segurança, inclusive políticas de promulgação e procedimentos que regulamentem o uso e a revisão da imposição e da liberação de qualquer forma de separação involuntária" (ONU, 2016, p. 26).
}

Revista de Direitos Fundamentais \& Democracia, Curitiba, v. 26, n. 1, p. 87-118, jan./abr. 2021. 
o da pessoa privada de liberdade e o da criança que transita pelo cárcere.

Dispositivos internacionais sobre o encarceramento abordam a visitação no contexto da promoção de "contato com o mundo exterior". O isolamento, a privação sensorial e a restrição de comunicações com familiares são práticas consideradas como violações de direitos humanos, razão pela qual esses dispositivos trazem prescrições mínimas evitando essas condutas, na forma de normas que aderem implicitamente à possibilidade de que a privação de contato, isolamento e segregação sejam penas impostas, inclusive passíveis de regulação. O Conselho da Europa editou as European Prison Rules em 1973, apresentando recomendações para a produção de normas sobre presídios, posteriormente revisadas em 2006. No texto, o direito à visitação deve servir a pessoas privadas de liberdade para a manutenção dos vínculos familiares; contudo, pode ser restrito e monitorado pelas autoridades para a convivência de investigações, segurança, prevenção criminal e após a realização de faltas disciplinares. A norma exige que essas restrições devam sempre manter um mínimo de contato da pessoa em prisão com o mundo externo, elencando como boa prática um número de visitas, cartas e chamadas telefônicas (EUROPE, 2003, p. 12).

O principal documento internacional para balizas mínimas na operação de sistemas penitenciários consiste nas já mencionadas "Regras de Mandela", adotadas em 1955 e revisadas em 2015, que assim abordam a questão da visitação:

\footnotetext{
Regra 58

1. Os prisioneiros devem ter permissão, sob a supervisão necessária, de comunicarem-se periodicamente com seus familiares e amigos, periodicamente:

(a) por correspondência e utilizando, onde houver, de telecomunicações, meios digitais, eletrônicos e outros; e

(b) por meio de visitas.

2. Onde forem permitidas as visitais conjugais, este direito deve ser garantido sem discriminação, e as mulheres presas exercerão este direito nas mesmas bases que os homens. Devem ser instaurados procedimentos, e locais devem ser disponibilizados, de forma a garantir o justo e igualitário acesso, respeitando-se a segurança e a dignidade (ONU, 2016, p. 31).
}

O ingresso dos visitantes pode ser condicionado ao consentimento em submeter-se a procedimentos às visitas, que devem seguir princípios de dignidade humana, privacidade, proporcionalidade, legalidade e necessidade. As Regras de Mandela indicam que as crianças não devem sofrer revistas íntimas ${ }^{8}$. A dinâmica de

\footnotetext{
8 De forma mais específica, a Regra 60 menciona que "revistas em partes íntimas do corpo devem ser evitadas e não devem ser utilizadas em crianças" (ONU, 2016, p. 60). A mesma regra indica que a revista deve ser consentida pela visita, que pode revogar tal consentimento a qualquer tempo.
}

Revista de Direitos Fundamentais \& Democracia, Curitiba, v. 26, n. 1, p. 87-118, jan./abr. 2021. 
sanções e a relação entre acesso das crianças ao cárcere são exploradas com mais detalhamento nas Regras de Bangkok, ou Regras das Nações Unidas para o Tratamento das Mulheres Presas e Medidas não Privativas de Liberdade para Mulheres Infratoras (ONU, 2016), cujo foco é estabelecer parâmetros mínimos para o cumprimento de penas por mulheres e seu desencarceramento, levando em conta especialmente o contexto da maternidade, como um complemento às diretrizes contidas nas Regras de Mandela. O texto adiciona a diretriz de incentivo para o contato das mulheres presas com os filhos ${ }^{9}$ e o ambiente propício de realização de visitas ${ }^{10}$.

Há, nas Regras de Bangkok, mais reforço discursivo à importância da visitação de crianças, o que retoma a hipótese de que infância e maternidade são problemas que chegam juntos às normas sobre prisão. Essa preocupação reaparece quando o texto aborda as disposições sobre sanções disciplinares, vedando sanções de isolamento ou segregação para mulheres com filhos ou amamentando, como estabelece a Regra 22: "não se aplicarão sanções de isolamento ou segregação disciplinar a mulheres gestantes, nem a mulheres com filhos/as ou em período de amamentação", e a Regra 23, que dispõe que nenhuma sanção disciplinar pode conter afastamento ou proibição de contato com a família.

Apesar de um fundamento normativo mínimo disposto constitucionalmente ou internacionalmente, as leis não criam mudanças automáticas no mundo real. $\mathrm{A}$ "efetivação" sobre esses direitos atravessará as dinâmicas normativas do cárcere que são gerenciados pelos órgãos de gestão penitenciária e da justiça. Rodrigo Roig (2011) explica que a execução penal, no Brasil, orbita em torno do binômio "legalidade/ discricionariedade": quaisquer atos, no âmbito da execução penal, precisam ter previsão legal, a fim de que se possa assegurar tratamento isonômico e justo a todas as pessoas que cumpram pena no Brasil. Regras gerais sobre direitos da pessoa presa e os deveres do Estado como mantenedor e executor das penas estão dispostos nos artigos 10 a 43 da Lei de Execução Penal (BRASIL, 1984), em atendimento a comandos constitucionais que indicam o respeito à integridade física e moral das pessoas presas, o direito de permanência de mulheres presas, com seus filhos,

\footnotetext{
9 "Regra 26 - Será incentivado e facilitado por todos os meios razoáveis o contato das mulheres presas com seus familiares, incluindo seus filhos/as, quem detêm a guarda de seus filhos/as e seus representantes legais. Quando possível, serão adotadas medidas para amenizar os problemas das mulheres presas em instituições distantes de seus locais de residência" (ONU, 2015, p. 28).

${ }^{10}$ Regra 28 - Visitas que envolvam crianças devem ser realizadas em um ambiente propício a uma experiência saudável, incluindo no que se refere ao comportamento dos funcionários, e deverá permitir o contato direto entre mães e filhos. Se possível, deverão ser incentivadas visitas que permitam uma permanência prolongada dos filhos (ONU, 2015, p.29).
}

Revista de Direitos Fundamentais \& Democracia, Curitiba, v. 26, n. 1, p. 87-118, jan./abr. 2021. 
durante o período da amamentação; dentre outros igualmente importantes, como a vedação a tratamento cruel, desumano ou degradante e a imposição do devido processo legal a processos judiciais ou administrativos ${ }^{11}$. Assim, apesar de ser um "direito" de simples apreensão nos textos constitucional e legal, a "eficácia da norma" dependerá mais da gestão do cotidiano e dessas normas subsidiárias, e menos da disposição simbólica registrada em texto constitucional.

Uma nova disputa política se realizou quando foi promulgada a Lei $n^{\circ} 12.962$, que alterou o Estatuto da Criança e do Adolescente (ECA) para incluir dispositivos que asseguram a convivência da criança e do adolescente com pais privados de liberdade, por meio de "visitas periódicas promovidas pelo responsável ou, nas hipóteses de acolhimento institucional, pela entidade responsável, independentemente de autorização judicial" (BRASIL, 2014). Além disso, garantiu que a condenação prévia por crime não implica na destituição do poder familiar, exceto na condenação por crime doloso apenado com reclusão contra o próprio filho - hipótese ampliada pela Lei $n^{\circ}$ $13.715 / 2018$ para o mesmo tipo de delito dirigido contra o outro titular do poder familiar ou outros filhos e descendentes. Esta lei se originou do Projeto de Lei $n^{0} 2.785$ de 2011, apresentado pela então Presidenta Dilma Rousseff ao Congresso Nacional ${ }^{12}$. A proposição expressou preocupação com a criação de mecanismos que assegurassem a convivência da criança e do adolescente com pais e mães em privação de liberdade, sem motivação de perda do poder familiar e como um mecanismo de "ressocialização" (BRASIL, 2011, p. 3). Tais preocupações seriam reiteradas na Lei $n^{\circ} 13.509$, de 22 de novembro de 2017, que alterou diversas legislações, como, novamente, o próprio ECA, garantindo a convivência da mãe adolescente em acolhimento institucional com a criança e a presença dos genitores em privação de liberdade nas oitivas realizadas.

Esta proposição legislativa passou por três Comissões na Câmara dos Deputados e foi aprovado por unanimidade em todas. Na Comissão de Segurança Pública e Combate ao Crime Organizado, o voto do relator, Dep. Marllos Sampaio (PMDB), trouxe como fundamento a preocupação com o aumento da população carcerária, a condição de vulnerabilidade do cárcere e casos identificados pela Pastoral

\footnotetext{
11 Podem ser citados, mais especificamente, como balizas de tal atuação, o art. $5^{\circ}$, incisos III, XXXVII, XXXIX, XLI, XLV, XLVII, XLVIII, XLIX, L, LIII, LIV e LV da Constituição Federal (BRASIL, 1988).

${ }^{12} \mathrm{Na}$ Exposição de Motivos do Projeto de Lei, destaca-se: "A presente iniciativa surgiu a partir da realidade enfrentada por mães privadas de sua liberdade em relação ao exercício de seu poder familiar. Como possíveis causas da quebra dos laços familiares da pessoa presa, podemos apontar a dificuldade do acesso à Justiça e a ausência de legislação que promova e garanta, efetivamente, condições para manutenção dos vínculos afetivos entre pais e filhos" (BRASIL, 2011, p. 3).
}

Revista de Direitos Fundamentais \& Democracia, Curitiba, v. 26, n. 1, p. 87-118, jan./abr. 2021. 
Carcerária de processos de destituição familiar que ocorreram à revelia das mães em privação de liberdade. Sobre o direito à visita, o relator afirmou:

\begin{abstract}
Em uma análise preliminar, as alterações aos arts. 19 e 23 estão em plena consonância com o princípio universal do "melhor interesse da criança" (art. $3^{\circ}$, I, da Convenção Internacional sobre os Direitos da Criança - ratificada pelo Brasil em 1990), o princípio constitucional da prioridade absoluta a crianças e adolescentes e o direito fundamental à convivência familiar, expressos no art. 227 da Constituição Federal. Além disso, a proposta também está de acordo com a Declaração Universal dos Direitos da Criança, no que diz respeito a que 'não se deverá separar a criança de tenra idade de sua mãe'. Sob o ponto de vista da segurança pública é benéfica, quando valoriza o contato familiar, o que pode aumentar a chance de ressocialização bem sucedida do custodiado adulto. O convívio familiar é tão importante que apenas deve ser considerado contrário ao melhor interesse da criança quando colidir com os (igualmente) direitos fundamentais à vida, à saúde, à liberdade, ao respeito e à dignidade. Apenas nos casos em que os próprios familiares da criança desrespeitam ou descuidam da sua integridade física, psíquica ou moral, é possível falar, em tese, sobre convivência familiar que não atende o melhor interesse da criança. Em todos os outros casos, deve o Estado providenciar, com prioridade absoluta, todo o necessário para que o direito à convivência familiar possa ser exercido regularmente" (BRASIL, 2012, p. 3).
\end{abstract}

A inovação legislativa, por si, não garantiu a realização de visitas, mas provocou o campo burocrático a reorganizar suas dinâmicas normativas e gerenciais em torno dessa nova autorização legal. A própria redação do dispositivo foi alvo de embate: o texto garante o direito à visitação por meio de duas formas: visitas periódicas promovidas pelo responsável e visitas periódicas promovidas pela entidade de acolhimento institucional, na hipótese de tal medida ocorrer. Contudo, há dúvida se a inexigibilidade de autorização judicial se aplica em ambos os casos ou somente ao último. Os argumentos para a inexigibilidade em ambos os casos caminham no sentido da garantia integral do direito, diante do seu caráter de direito fundamental; já para a inexigibilidade apenas no último caso, partem da ideia de que a anuência de um poder responsável já teria sido dada a partir da promoção da visita pela entidade de acolhimento e que a criança ou adolescente em acolhimento estaria em situação maior de vulnerabilidade, o que demandaria celeridade e menos burocratização para a efetivação da visita.

Por outro lado, a mesma proteção à criança também fundamenta, em nível jurisdicional, o cerceamento da visitação. Restrita jurisprudência do Superior Tribunal de Justiça (STJ) traz o entendimento de que o direito à visitação não é absoluto e depende de ponderação, realizada caso a caso. Quando é chamado a se posicionar sobre casos relacionados à visitação de crianças a familiares distintos dos genitores, o tribunal afirma tal circunstância, ou ainda:

Revista de Direitos Fundamentais \& Democracia, Curitiba, v. 26, n. 1, p. 87-118, jan./abr. 2021. 
[...] o direito de visitação, com o objetivo de ressocialização, não deve se sobrepor aos direitos dos menores. Isto porque os estabelecimentos prisionais são, por sua própria natureza, ambientes impróprios à formação psíquica e moral de crianças e adolescentes, cuja proteção integral tem base constitucional, nos termos do art. 227 da Constituição Federal (BRASIL, 2016).

Segundo reiterada jurisprudência deste Tribunal Superior, o direito de visita, disposto no art. 41, X, da Lei de Execução Penal, embora seja relevante para o processo de reinserção do preso à sociedade e imprescindível para a manutenção dos laços familiares, não ostenta natureza absoluta e deve ser concedido após a análise das circunstâncias do caso concreto. Desse modo, indeferido o pedido de visitação com fulcro na necessidade de assegurar a integridade física e psíquica do menor (sobrinho do agravante), conferindo-se máxima efetividade à norma inserta no art. 277 da Constituição Federal, não há se falar em ofensa ao art. 41, X, da Lei n. 7.210/1984. Inclusive, há diversos julgados no sentido de que a proteção integral aos menores deve preponderar sobre o direito do preso de receber visitas (BRASIL, 2018)

\section{A repetição dos argumentos ilustra como a narrativa de proteção à criança} ganha interpretação diversa da proposta pelo sistema legal ao relativizar o direito da visitação. Apesar de os casos acima abordarem relações familiares diversas das de pai/mãe e filhos, há um caso em que a mesma narrativa fundamenta o cerceamento de visitação do apenado por três filhos menores, apontando que os autos do caso não trazem comprovação de vínculo afetivo entre o pai e as crianças ${ }^{13}$. Apesar de ser pouco compreensível (diante da complexidade natural de qualquer caso do gênero) por meio da leitura apenas de uma decisão monocrática do STJ, nota-se que houve o uso, pela jurisprudência, de requisito nunca disposto em lei - a comprovação do vínculo afetivo - para cercear um direito garantido pela legislação. Nos casos em que se abordam relações familiares distintas de paternidade e maternidade, a existência de vínculo afetivo é requisito que poderia, inclusive, ampliar o espectro de alcance do direito à visitação - demonstrando que tal vínculo é forte o suficiente para garantir uma

13 Nos trechos da decisão questionada e mantida pelo STJ: "Destaco que o direito do preso ao convívio familiar, não pode ser absoluto, podendo ser suspenso ou restrito, exatamente quando a pessoa visitante se tratar de uma pessoa com personalidade ainda em formação. Por certo, o interesse pessoal do apenado não pode prevalecer à proteção integral assegurada às crianças e adolescentes, prevista na Constituição Federal, que leva em conta sua especial condição de pessoas em desenvolvimento, sendo dever de todos zelar pela sua dignidade, pondo-as a salvo de qualquer tratamento desumano, violento, aterrorizante, vexatório ou constrangedor, conforme explicita o artigo 18 do ECA. Logo, o ingresso de menores no estabelecimento prisional afronta às disposições de proteção do referido diploma legal, pois o presídio é um ambiente hostil, com graves problemas psicossociais, como a violência, a angústia, a tensão emocional e até possível situação de motim, que podem colocar em risco a saúde física e psicológica de qualquer pessoa, muito mais de uma criança. Há, pois, clara contraindicação de visita de crianças e adolescentes aos presídios. Além disso, na hipótese, a cassação da autorização para a visita do menor de idade é medida que se impõe e visa, primordialmente, à garantia da integridade física, psíquica e moral dos menores [...], que apesar de serem filhos do apenado, não há nos autos comprovação de vínculo afetivo, e até porque ainda estão em idade muito tenra, sendo desaconselhável que frequente o local" (BRASIL, 2019, p. 2-3).

Revista de Direitos Fundamentais \& Democracia, Curitiba, v. 26, n. 1, p. 87-118, jan./abr. 2021. 
extensão da norma aos genitores. Contudo, junta-se à relativização do direito à visitação para contrariar a expectativa de realização da visitação trazida pela mudança normativa.

A análise, que não busca partir do pressuposto de que o direito à visitação seja absoluto, revela que sua aparente relativização acaba por torná-lo não aplicável à jurisprudência. Nas decisões exemplificadas, a preservação da integridade da criança torna absoluto o sentido de proteção integral: é mais nocivo o cárcere do que a perda do vínculo familiar. Sobre os efeitos da interação das crianças com o cárcere, há posições que associam o contato com o ambiente prisional e problemas como abuso de álcool, drogas e baixo desempenho escolar (DUARTE, 2015). Além disso, no campo dos efeitos do aprisionamento, discute-se a relação das famílias com o cárcere a partir da "hipótese da desestruturação", que subjaz a ideia da prisão como efeito de desestabilização familiar e a transmissão dos efeitos sociais do cárcere, tão estudados pelas ciências criminais, às famílias dos presos (COMFORT, 2010; GODOI, 2011).

Ainda assim, os acúmulos empíricos são poucos para subsidiar esse movimento da jurisprudência. Duarte (2015), por exemplo, aponta o ambiente do cárcere como o único passível de promoção da convivência entre pais e filhos ${ }^{14}$. Godoi, por sua vez, chama para uma reconfiguração dos estudos sobre os efeitos sociais do encarceramento, distanciando-se da hipótese da desconstrução familiar, para que se entenda que "a prisão se torna uma instituição socializadora de amplas parcelas da população, passando afazer parte do cotidiano de um número cada vez maior de pessoas e a reestruturar sociabilidades familiares e comunitárias" (GODOI, 2011, p. 149).

No cenário construído, a "eficácia" sobre o direito de visitação encontra a complexa disputa entre práticas, normas e panoramas sobre os efeitos do cárcere, o que deixa um conjunto de questões ainda não exploradas sobre o tema. Em primeiro lugar, a lei autorizou visitação de criança aos seus genitores; contudo, as famílias são muito mais diversas do que a relação entre mães e pais biológicos. Visitas de crianças a avós ou avôs, padrastos e madrastas, irmãs e irmãos continuam fora da categoria de visita cuja autorização judicial é dispensada. Desse modo, qual tipo de família a lei

14 "De fato, os filhos fazem parte da rotina de visitas nas unidades prisionais, porque nos dias em que não há visita íntima para o casal, muitas mães levam as crianças para ver o pai. Há casos em que o preso apenas conhece o filho "do lado de dentro" da prisão, já que há situações em que o filho é concebido na visita íntima. Portanto, a prisão ajudaria de certa forma a reforçar as relações familiares, haja vista que, entre outras situações, o local se tornaria palco do estreitamento dos laços afetivos entre o casal, bem como abre espaço à discussão entre os parceiros acerca da concepção de uma criança" (DUARTE, 2015, 152-153).

Revista de Direitos Fundamentais \& Democracia, Curitiba, v. 26, n. 1, p. 87-118, jan./abr. 2021. 
visou à proteção? Em segundo lugar, se há dialética em torno do direito de visita, que ora pode ser lido como direito da criança, ora lido como direito do genitor, diante da situação desumana dos presídios, como a ponderação entre esses direitos é realizada? Em que medida o convívio familiar no cárcere é direito que se sobrepõe à blindagem de crianças ao ambiente da prisão?

Em terceiro lugar: como a lei pode interagir com o cumprimento do Regime Disciplinar Diferenciado? Caso a pessoa em privação de liberdade cometa algum crime doloso dentro do cárcere (conduta considerada "falta grave"), apresente risco à ordem ou segurança do estabelecimento, ou sobre ele "recaia fundadas suspeitas de envolvimento em organizações criminosas", poderá ser submetido a um conjunto de práticas institucionais definidas no art. 52 da LEP: recolhimento em cela individual, saída diária da cela por duas horas para banho de sol e restrição das visitas para duas pessoas por semana, com duração de duas horas - sem contar as crianças. Embora que seja autorizado que crianças visitem presos que estejam em RDD, essas visitas poderão ser suspensas pela imposição do Regime?

Por último, como as exigências de segurança para o ambiente prisional como revistas, limitações e vigilância se relacionam com a presença de crianças? O que a regulação sobre a entrada desses sujeitos nos diz sobre penas, segurança e imaginários sobre as pessoas que existem junto ao cárcere? Essas e outras perguntas são lacunas de pesquisa sobre as quais tentaremos trazer alguns indícios empíricos a partir da regulação de visitas no sistema penitenciário do Distrito Federal.

\section{REGULAÇÕES E SENTIDOS DA VISITA SOCIAL NO DISTRITO FEDERAL}

A administração penitenciária do Distrito Federal é de competência da Secretaria de Administração Penitenciária, que possui, dentre suas atribuições, a expedição das normas e organização dos procedimentos das 7 unidades que estão sub sua competência: Centro de Detenção Provisória (CDP); Centro de Internamento e Reeducação (CIR); Penitenciária do DF - I (PDF - I); Penitenciária do DF - II (PDF-II); Penitenciária Feminina do DF (PFDF); Centro de Progressão Penitenciária - CPP; Diretoria Penitenciária de Operações Especiais (DPOE) (DISTRITO FEDERAL, 2020, online).

O Distrito Federal possui um "Regimento Interno dos Estabelecimentos Penais" desde 1988, que regula, dentre outras questões, o exercício das sanções no 
estabelecimento prisional. A visita é um evento que aparece no regimento sob três formas: como direito, conforme previsto naLEP ${ }^{15}$; como favor, concedido pela Diretoria do Estabelecimento, inclusive fora dos horários e dias estabelecidos ${ }^{16}$; e como possiblidade de restrição por sanção, já que entre as penalidades aplicadas pelo regime disciplinar da prisão está a suspensão ou restrição dos direitos do art. 41 da LEP - dentre eles, a visita; e, nas sanções secundárias, a perda dos favores ${ }^{17}$.

Para a realização das visitas, cada unidade possui uma dinâmica diferente. Partimos da análise das informações publicadas por três dessas unidades: PDF I, PDF II e PFDF. São regras gerais para a visitação o cadastro prévio de visitantes por preso, o que pode ser realizado em agências do "Na Hora", conjunto de serviços públicos do Governo do Distrito Federal em várias cidades-satélites; serviços de atendimento aos cidadãos do DF, como emissão de certidões, identidades e carteiras de trabalho. Cada pessoa em privação de liberdade poderá listar até 10 (dez) pessoas que poderão visitála, elencando grau de parentesco ou tipo de relação. Em cada dia de visita a pessoa poderá receber até 4 visitantes, que deverão ter realizado cadastramento prévio, apresentar documentação necessária (identidade e comprovante de residência originais e com cópia) e passar pelos procedimentos de revista.

A informação sobre a visitação de crianças não é devidamente clara no portal de informações do Tribunal de Justiça do Distrito Federal e dos Territórios (TJDFT), que ora informa que todos os pedidos de visitas de "menores" devem ser encaminhados à Vara de Execução Penal, ora dispensa a exigência, e ainda se faz remissão a duas portarias já revogadas (Portarias números 11/2003 e 17/2003, ambas revogadas pela Portaria $\left.n^{\circ} 08 / 2016\right)^{18}$ (TJDFT, 2016).

\footnotetext{
15 "Art. 125. São direitos específicos do interno: [...] V. ser visitado por seu cônjuge ou companheira (o) e pelos parentes e amigos, nos dias e horários estabelecidos" (DISTRITO FEDERAL, 1988, p. 22).

16 "Art. 131 - São favores a serem concedidos gradativamente aos internos; I. visitas de parentes em qualquer grau e de pessoas amigas, em dias certos e em número limitado; II. visitas especiais, fora do horário normal; III. visitas íntimas da esposa (o) ou companheira (o); [...]X. visita ao local onde se encontra ascendente, descendente ou cônjuge, enfermo e em estado grave;" (DISTRITO FEDERAL, 1988, p. 23-24).

17 "Art. 90 - Aplicam-se aos presos infratores as seguintes sanções principais: I. advertência verbal; II. repreensão escrita; III. suspensão ou restrição de direitos (art. 41, § único da LEP); e IV. isolamento na própria cela ou em cela especial. Art. 91 - Consideram-se sanções secundárias: I. perda de favores; II. suspensão de visita concedida em caráter de favor; III. rebaixamento de classificação disciplinar; e IV. apreensão de valores ou objetos" (DISTRITO FEDERAL, 1988, p. 15).

${ }^{18}$ Antes da norma atual, a Vara de Execução Penal regulava a visita de crianças por meio da Portaria ${ }^{\circ}$ 001/2001, que trazia a seguinte disposição: "Todas as crianças e adolescentes que tiverem interesse em visitar parentes internos no Sistema Penitenciário, nas instituições militares e nas delegacias de polícia, deverão requerer mediante petição subscrita pelo responsável legal, o competente pedido de autorização para entrar e permanecer nas instituições acima referidas. Tosos os pedidos serão examinados pelos Juízes da Vara de Execuções Criminais (sic), defendo ser remetidos a esse órgão judiciário os que forem apresentados à Vara da Infância e da Juventude" (TJDFT, 2001, p.1).
}

Revista de Direitos Fundamentais \& Democracia, Curitiba, v. 26, n. 1, p. 87-118, jan./abr. 2021. 
Por meio da Portaria n 11 de 2003, a Vara de Execução Penal dispensou a autorização judicial para crianças menores de um ano, desde que acompanhadas pelos genitores e para visitar pai ou mãe. A regulação atualmente vigente sobre a visitação no Distrito Federal - a Portaria VEP nº 8/2016 - está fundamentada em diversos dispositivos legais, dentre elas a modificação do ECRIAD promovida pela Lei n 13.509/2017 (TJDFT, 2016). A portaria disciplina não só as visitas sociais ordinárias, mas também as visitas médicas, acadêmicas e jornalísticas. Sobre a entrada de crianças, a Portaria autoriza a entrada de menores de 18 anos apenas para visitar pais e mães em cumprimento de pena, e sempre acompanhadas de responsável. Além disso, enteados e enteadas são equiparados aos filhos desde que haja comprovação e caso a criança seja vista desacompanhada haverá a interrupção da visita e possível suspensão. Em relação aos adolescentes, entre 16 e 18 anos, é possível a visita para cônjuges e companheiros, incluindo visita íntima, desde que autorizadas por responsável e que comprove casamento ou união estável (TJDFT, 2016).

O horário da visitação é outra informação desencontrada. O sítio eletrônico do TJDFT possui uma página de informações para visitantes do sistema prisional, elenca que a visitação nos três estabelecimentos ocorre às quintas-feiras, das 9 às 15 horas e o visitante poderá ingressar no estabelecimento até às 12 horas (TJDFT, 2020, online). Contudo, no portal eletrônico das unidades prisionais, essa é a informação de visitação vigente apenas para as unidades masculinas. Na Penitenciária Feminina do Distrito Federal (PFDF), segundo a cartilha do visitante, as visitas ocorrem às quintas-feiras, das 7 horas e 30 minutos até às 12 horas (DISTRITO FEDERAL, 2018).

Os visitantes devem "retirar senhas" no início da manhã, disponibilizadas até às 12 horas e que limitam o ingresso de pessoas no estabelecimento. Além disso, existem limites de cadastramento de visitantes que são iguais nos três estabelecimentos. A pessoa presa provisoriamente poderá cadastrar até 4 pessoas para visitá-lo, dentre os quais 3 familiares e um amigo. Já o interno pode cadastrar até 10 pessoas, sendo 9 familiares e um amigo. Essa diferenciação viola a Lei de Execução Penal, que assegura a igualdade na garantia de direitos ao preso provisório, e as Regras de Mandela, nas quais são nomeados "presos sem julgamento", que devem ser tratados como inocentes (ONU, 2016, p. 42). As orientações aos visitantes também determinam as roupas, calcados e peças íntimas exigidas para os visitantes, que também são aplicáveis às crianças (DISTRITO FEDERAL, 2018, p. 4). 
Diferente dos demais presídios, os estabelecimentos federais são normatizados por norma única, atualmente, a Portaria n 157 de 12 de fevereiro de 2019, editada pelo Departamento Penitenciário Nacional, que revogou a Portaria DEPEN $n^{\circ} 54$, de 2016. Segundo as regras anteriores, era permitida a visita de até três pessoas, sem contar crianças, em área destinada pela direção do estabelecimento. Demais visitantes tinham direito à visitação pelo parlatório. Crianças e adolescentes estavam autorizados a visitar os presos ${ }^{19}$, desde que fossem descendentes, enteados ou enteadas, irmãos, irmãs, sobrinhos ou sobrinhas da pessoa. A autorização judicial somente era exigida quando o acompanhante da criança não fosse seu responsável legal, e a normativa vedava a revista íntima a crianças (BRASIL, 2016, p. 4). A Portaria DEPEN no 157/2019 também revogou a Portaria $n^{\circ} 10$, de agosto de 2017 , editada pela Diretoria do Sistema Penitenciário Federal, a qual dispunha sobre horários e regras para as visitas sociais, íntimas e de advogados. Esse texto definia que as visitas sociais com contato físico ocorreriam com duração de três horas e que, em caso de presos em RDD, as visitas ocorreriam no parlatório pelo período de duas horas. $\mathrm{Na}$ disciplina sobre roupas e objetos, a portaria permitia que crianças de até três anos ingressassem com uma fralda e uma chupeta, e para crianças de até seis anos, dois recipientes de até $250 \mathrm{ml}$ com água, leite ou sucos líquidos.

As regulações sobre o ingresso das crianças no cárcere muitas vezes são, por si só, obstáculos para a entrada. Submeter as crianças ao procedimento de revista, ao consumo de comidas restritivas que devem durar não somente o tempo da visita, mas o trajeto entre o cárcere e casa, se somam às preocupações dos próprios responsáveis com a exposição da criança e o contexto da prisão. Nesse sentido, a pesquisa de Marcia Beckman sobre as representações de crianças em idade pré-escolar com pais presos na rede pública de ensino de Campinas (SP) agrega informações interessantes. Segundo a autora, os próprios familiares não representam a prisão como espaço para as crianças e, assim, dosam as visitas ao cárcere, levando em conta fatores como a revista vexatória e os pedidos dos familiares em cárcere; no entanto, acreditam "que não levar a criança é uma medida de proteção; contudo a família não percebe que manter a vinculação da criança com o pai é um fator de proteção" (BECKMAN, 2007, p. 94).

19 Segundo o InfoPen de 2020, não há nenhuma mulher cumprindo pena ou presa provisoriamente no sistema penitenciário federal (BRASIL, 2020b). Esse dado precisa de uma investigação mais apurada, com perspectiva de gênero, para que se discuta o parâmetro de aprisionamento das chamadas "grandes lideranças das organizações criminosas".

Revista de Direitos Fundamentais \& Democracia, Curitiba, v. 26, n. 1, p. 87-118, jan./abr. 2021. 
A questão de alteração nas normas possui outro contexto: as visitas estão restritas ao parlatório e supervisionadas, com exceção das visitas dos presos com "perfil de réu colaborador ou delator premiado" 20 , que terão direito à visita em pátio de visitação. Ou seja, argumenta-se aqui que a modificação visa incentivar a realização das colaborações através da restrição do contato do preso - provisório ou não - com amigos e familiares. A portaria é atualmente alvo de Arguição de Descumprimento de Preceito Fundamental $n^{\circ} 518$, ajuizada pelo Instituto Anjos da Liberdade e pelo Partido dos Trabalhadores, sob a relatoria do Ministro Edson Fachin (BRASIL, 2019). Na argumentação dos proponentes, a restrição aos direitos de visitação é incompatível com pressupostos de igualdade, o sigilo da comunicação entre cliente e advogado, pune as famílias e visa incentivar a realização de colaborações premiadas por meio da privação das pessoas presas do contato com seus entes queridos. Segundo a petição inicial, o direito à visitação não é apenas da pessoa presa, mas também de todos os membros da família:

É com apoio no direito comum que vincula pais e filhos, companheiros e cônjuges, que as proibições genéricas de visita social e visita humanizada são consideradas aviltantes à dignidade da pessoa humana e a discriminação de tratamento, que está evidente na previsão do $\S 1^{\circ}$ da Portaria $n^{\circ} 157 / 2049$, em favor de condenados colaboradores, é tida como inaceitável, pois violadora de direitos fundamentais (BRASIL, 2019, p. 15).

No Distrito Federal, disputas judiciais em torno do direito à visitação são encontradas em Agravos à Execução interpostos ao TJDFT. Apesar da independência da autorização judicial, os visitantes ainda precisam realizar registros e apresentar documentações. Contudo, algumas situações são indeferidas pela Vara de Execução Penal e recorridas pela Defensoria Pública do DF. Em pesquisa com lapso temporal entre abril de 2017 a abril de 2019 na jurisprudência do TJDFT, contendo as palavraschave "agravo à execução"; "visitação"; "criança", foram identificados sete acórdãos sobre o tema. Todos traziam sujeitos diversos dos genitores: dois tratavam de visitação de enteada; dois sobre visitação de sobrinha; e os outros sobre a visitação de irmãs.

${ }^{20}$ Art. $2^{\circ}$ As visitas sociais nos estabelecimentos penais federais de segurança máxima serão restritas ao parlatório e por videoconferência, sendo destinadas exclusivamente à manutenção dos laços familiares e sociais, e sob a necessária supervisão, em conformidade à Regra 58 das Regras Mínimas das Nações Unidas para o Tratamento de Reclusos e ao Decreto $\mathrm{n}^{\circ} 6.049$, de 2007. $\S 1^{\circ} \mathrm{O}$ disposto no caput não se aplica aos presos com perfil de réu colaborador ou delator premiado e outros cuja inclusão ou transferência não estejam fundamentadas nos incisos, I a IV e VI do art. $3^{\circ}$ do Decreto $\mathrm{n}^{\circ} 6.877$, de 2009 , sendo permitida a visita social em pátio de visitação. $\S 2^{\circ} \mathrm{A}$ visita social em parlatório de que trata o caput será assegurada ao cônjuge, companheira, parentes e amigos, separados por vidro, garantindose a comunicação por meio de interfone (BRASIL, 2019, online).

Revista de Direitos Fundamentais \& Democracia, Curitiba, v. 26, n. 1, p. 87-118, jan./abr. 2021. 
Em todos os casos, as visitantes eram mulheres e o conflito de direito se pautava, de um lado, a proteção integral à criança e ao adolescente, blindando-as do ambiente do cárcere; e do outro, o direito do preso ao convívio familiar como forma de ressocialização.

Como ilustração do cenário compreendido, apresentamos dois casos. O primeiro, julgado pela $1^{a}$ Turma Criminal, consistia em negativa de autorização de visita de irmã de 9 anos, acompanhada da mãe. A decisão de indeferimento ao pedido de visitação foi mantida em segunda instância. No voto vencido, o Desembargador argumenta pelo direito de visita, indicando que "o que realmente importa é o sentimento de amor familiar (paternal ou fraternal) que pode ajudar a resgatar a dignidade e autoestima do preso, indispensável à harmônica integração social (TJDFT, 2017, p. 6). Já no argumento da Desembargadora que orientou o voto vencedor, é necessário preservar a criança da "nocividade prisional": "nesse caso, a visitação é regulada não no interesse do detento, mas no da criança. Não se justifica, in casu, a exposição da menor aos riscos e constrangimentos naturalmente encontrados no ambiente carcerário. $\mathrm{Na}$ ponderação de valores, prepondera a proteção integral à criança" (TJDFT, 2017, p. 8).

Já em caso diverso, julgado pela $2^{\mathrm{a}}$ Turma Criminal, a decisão foi reformada. $\mathrm{O}$ pedido de autorização de visita de irmã adolescente, de 16 anos, foi concedido ao irmão:

\begin{abstract}
Não se pode olvidar a necessidade de resguardo à integridade física da criança e do adolescente, que serão colocados em perigo, ante o risco de surgir alguma intercorrência disciplinar por parte dos internos. Ocorre que presume-se aos maiores de 16 e menores de 18 anos já possuírem maturidade suficiente para a prática de certos atos civis, tais como o exercício da cidadania por meio do voto de seus representantes políticos. Assim, considerando possuir certa maturidade, a adolescente apresenta condições suficientes para enfrentar os riscos e constrangimentos naturais a que está exposta no ambiente do estabelecimento prisional. E se assim é, pode-se permitir a visita da referida menor desde que acompanhada por sua representante legal, no caso dos autos, assistida por sua genitora. Portanto, o direito do preso de receber visitas pode ser conciliado com o princípio da proteção integral da adolescente, mostrando-se razoável a autorização pleiteada, uma vez que tal medida revela-se possível, desde que a entrada no presídio de menor púbere seja franqueada com os cuidados necessários a serem providenciados pela direção do estabelecimento prisional e que garantam o resguardo da integridade física dos jovens visitantes, tendo em vista o preceito constitucional de proteção integral à criança e ao adolescente (TJDFT, 2017b, p. 8).
\end{abstract}

Por meio do que observamos sobre as limitações da legislação federal em torno da visitação de crianças ao cárcere, a tensão entre a proteção integral à criança e Revista de Direitos Fundamentais \& Democracia, Curitiba, v. 26, n. 1, p. 87-118, jan./abr. 2021. 
ao adolescente, a manutenção dos vínculos com a família e as crescentes esferas de controle dos órgãos da execução penal em relação às normativas estaduais e internas, surgem outras lacunas de pesquisa que podem ser objeto de trabalhos futuros. Em primeiro lugar, notamos que o ajuizamento de agravos à execução questionando direitos à visitação não é corriqueiro no Distrito Federal. Vale questionar se existem dinâmicas da gestão processual, especialmente na Defensoria Pública, que permitam que alguns casos sejam recorríveis e outros, não. Convém investigar mais a hipótese de Patrick Cacicedo (2018, p. 417), ao entender que a principal característica da jurisdicionalização da execução penal "é a sua lentidão, que acaba por torná-la um mecanismo muito mais violador do que garantidor dos direitos previstos em lei”.

Além disso, podemos investigar se existem autorizações para a visitação de crianças que fogem à regra de destinação para pais e mães e como elas são obtidas. Como mães, avós, tias, irmãs se adequam às normativas impostas de visitação, ressignificando as normas da administração prisional em práticas do cotidiano. Por fim, que representações sociais sobre família, maternidade, paternidade, adolescentes e crianças orientam a produção desses discursos sobre visitação aos presídios. No caso da visitação de crianças no cárcere, verifica-se o uso da less eligibility ${ }^{21}$ para estratégias e tensões em torno dessa aproximação da família com a execução penal.

\section{CONSIDERAÇÕES FINAIS}

Embora o direito articulado nos Tribunais referencie a proteção integral à criança e alegue que a prisão não é um lugar para elas, o fato é que crianças convivem com a realidade do cárcere. O dever-ser das normas e dos julgados entra em intensa contradição com a dinâmica do cotidiano das famílias impactadas pelo encarceramento, parcela significativa da população brasileira.

Primeiramente, há que se observar um arcabouço normativo que permite a visitação de crianças ao cárcere, considera que esse evento é a expressão do direito à convivência familiar e fundamenta o processo de ressocialização. Contudo, as normativas para o ingresso das crianças não versam sobre o bem-estar e a infraestrutura do cárcere para recebê-las. Ao contrário, expõem apenas os deveres aos

${ }^{21} \mathrm{O}$ princípio da less eligibility determina que as condições de vida no cárcere devem ser acentuadamente piores do que as condições de vida dos mais precários trabalhadores livres para que preserve seu caráter punitivo e se mantenha devidamente dissuasor diante do custo da opção de delinquir. Com relevante apoio político latente, o princípio revela a realidade da política criminal e penitenciária brasileira em seu percurso histórico (CACICEDO, 2015, p. 306).

Revista de Direitos Fundamentais \& Democracia, Curitiba, v. 26, n. 1, p. 87-118, jan./abr. 2021. 
responsáveis por essas crianças, como regulação de roupas, objetos, quantidades de alimento e submissão a revistas. A norma regula a relação extra-intramuros, estabelecendo os requisitos para que a segurança interna seja mantida mesmo que nada se modifique sobre situação de precariedade da visita.

Nesse ponto, juristas e gestores no campo prisional alegam a proteção às crianças como óbices ao ingresso no ambiente carcerário, julgado "nocivo", mas parece haver pouca preocupação com o dado dessas condições. Ademais, intuímos que as representações sociais que orientam o imaginário sobre as crianças que transitam pelo cárcere beira a inocência e a ausência de contato com ambientes de hostilidade e vulnerabilidade social. Ao mesmo tempo, parece haver uma segunda orientação, que representa crianças usadas como instrumentos de ruptura da segurança no cárcere, que precisam ter seus corpos e objetos regulados e vistoriados.

Outro ponto evidenciado pela pesquisa é a utilização do contato com as crianças como mecanismo de sanção. A vedação de visitação integra o rol de sanções administrativas aplicadas dentro do próprio cárcere, mas que atingem não somente o sujeito que cumpre a pena e está, de fato, submetido à disciplina prisional, mas também todos os sujeitos de sua rede familiar externa. Apesar dos inúmeros pontos de pesquisa evidenciados por essa sistematização normativa, a literatura e os dados sobre a relação entre crianças, visitação e cárcere é quase nula no Brasil, existente de forma significativa quando se discutem maternidade e prisão.

Respondendo à pergunta de pesquisa, entendemos que há limites institucionais que impedem o direito de visitação de crianças a seus familiares presos no Distrito Federal; tais limites são de ordem material, de ordem jurídica, de ordem social. Os arranjos institucionais entre os órgãos da execução penal, no DF, não parecem cooperar para a realização dos direitos das crianças e de suas famílias, desde os impedimentos normativos e disciplinares à visitação, desde a falta de estrutura adequada para a convivência e o trânsito no cárcere, até a pouca compreensão sobre os efeitos da convivência familiar para crianças e adultos.

Escrever sobre os sentidos do visitar para o campo jurídico, além de descrever procedimentos, normas e prescrições redigidas pelos agentes formais e informais de controle, do campo burocrático e do direito, é navegar por um espaço dos não-ditos. A visita não é um tema. Soma-se ao esforço de encontrar textos regulatórios sobre tais dados e a perspectiva de se reconhecer a visitação enquanto direito, o que fragiliza a revisão bibliográfica. Se encontrou pouca literatura específica sobre o tema, 
especialmente no Brasil, quando o assunto "visita" é mera menção, sem ônus argumentativo em torno de conflitos, limites e potencialidades da visita enquanto direito na execução penal. Diante disso, a importância do trabalho de revisão normativa é evidenciar a discussão sobre o tema da visitação de crianças, especialmente tensionando o enquadramento abordado nos Tribunais com a realidade carcerária brasileira, com as diversas dimensões de vulnerabilidade, na qual a ressocialização é um mito na mesma medida do discurso paternalista de blindagem das crianças à nocividade do cárcere. 


\section{REFERÊNCIAS}

BOUDIN, Chesa. Children of Incarcerated Parents: The Child's Constitutional Right to the Family Relationship. The Journal of Criminal Law and Criminology. Northwestern University School of Law, v. 101, n. 1, 2011, p. 77-118.

BRASIL. Câmara dos Deputados. Projeto de Lei n 335, de 18 de abril de 1995. Dá nova redação ao art. 89 da Lei n 7.210, de 11 de julho de 1984 (Lei de Execução Penal), que trata das penitenciárias de mulheres. Brasília, 2009. Disponível em: https://www.camara.leg.br/proposicoesWeb/fichadetramitacao?idProposicao=15320 Acesso em: 1 mar. 2020.

BRASIL. Câmara dos Deputados. Projeto de Lei nº 2.785 de 2011.Brasília, 25 de novembro de 2011. Disponível em:

https://www.camara.leg.br/proposicoesWeb/prop_mostrarintegra;jsessionid=A96AB2EA C821871C893EE3B409458C59. proposicoesWebExterno1? codteor $=943397 \&$ filename $=$ Tramitacao-PL+2785/2011Acesso em: 26 fev. 2020.

BRASIL. Câmara dos Deputados. Comissão de Segurança Pública e Combate ao Crime Organizado. Relatório ao Projeto de Lei $n^{\circ} 2.785$ de 2011. Brasília, 25 de abril de 2012. Disponível em:

https://www.camara.leg.br/proposicoesWeb/prop_mostrarintegra?codteor=986014\&file name=Tramitacao-PL+2785/2011 Acesso em: 27 fev. 2020.

BRASIL. Conselho Nacional de Justiça. Estatísticas BNMP. Brasília: CNJ, 2020a. Disponível em: https://portalbnmp.cnj.jus.br/\#/estatisticas Acesso em: 26 fev. 2020.

BRASIL. Conselho Nacional de Justiça. Relatório de Gestão - Supervisão do Departamento de Monitoramento e Fiscalização do Sistema Carcerário e do Sistema de Execução de Medidas Socioeducativas - DMF. Brasília: CNJ, 2017a.

BRASIL. Constituição da República Federativa do Brasil de 1988.Brasília: Presidência da República [2019]. Disponível em:

http://www.planalto.gov.br/ccivil_03/constituicao/constituicao.htm Acesso em: 26 fev. 2020.

BRASIL. Lei n 7.210, de 11 de julho de 1984. Institui a Lei de Execução Penal. Brasília: Presidência da República [2019]. Disponível em:

http://www.planalto.gov.br/ccivil_03/leis/l7210.htm Acesso em 26 fev. 2020.

BRASIL. Lei $\mathbf{n}^{\circ} \mathbf{8 . 0 6 9}$, de 13 de julho de 1990. Dispõe sobre o Estatuto da Criança e do Adolescente e dá outras providências. Brasília: Presidência da República [2019]. Disponível em: http://www.planalto.gov.br/ccivil_03/leis//8069.htm Acesso em: 26 fev. 2020.

BRASIL. Lei n $^{0}$ 12.962, de 8 de abril de 2014.Brasília: Presidência da República [2014]. Disponível em: http://www.planalto.gov.br/ccivil_03/_Ato20112014/2014/Lei/L12962.htm Acesso em: 29 fev. 2020.

BRASIL. Lei $\mathbf{n}^{\circ}$ 13.509, de 22 de novembro de 2017. Brasília: Presidência da 
República [2017b]. Disponível em: http://www.planalto.gov.br/ccivil_03/_Ato20152018/2017/Lei/L13509.htm Acesso em 27 fev. 2020.

BRASIL. Lei $\mathbf{n}^{\circ}$ 13.715, de 24 de setembro de 2018.Brasília: Presidência da República [2019], 2018a. Disponível em: http://www.planalto.gov.br/ccivil_03/_Ato20152018/2018/Lei/L13715.htm Acesso em 27 fev. 2020.

BRASIL. Ministério da Justiça e da Segurança Pública. Departamento Penitenciário Nacional. Conheça o Sistema Penitenciário Federal. Brasília, 3 de dezembro de 2019. Disponível em: http://depen.gov.br/DEPEN/conheca-o-sistema-penitenciariofederal-1 Acesso em 27 fev. 2020.

BRASIL. Ministério da Justiça e da Segurança Pública. Departamento Penitenciário Nacional. Portaria DEPEN $n^{\circ}$ 54, de 4 de fevereiro de 2016. Disponível em: http://depen.gov.br/DEPEN/dispf/cgtp/PortariaVisitas.pdf Acesso em 27 fev. 2020.

BRASIL. Ministério da Justiça e da Segurança Pública. Portaria nº 157, de 12 de fevereiro de 2019. [Disciplina o procedimento de visita social aos presos nos estabelecimentos penais de segurança máxima e dá outras providências]. 2019b.Disponível em: http://www.in.gov.br/materia/lasset_publisher/Kujw0TZC2Mb/content/id/63210175/do1e-2019-02-13-portaria-n-157de-12-de-fevereiro-de-2019-63210171 Acesso em 27 fev. 2020.

BRASIL. Ministério da Justiça. Levantamento Nacional de Informações

Penitenciárias InfoPen - Junho de 2014. Brasília: Ministério da Justiça/Fórum Brasileiro de Segurança Pública, 2015a.

BRASIL. Ministério da Justiça. Levantamento Nacional de Informações Penitenciárias - Atualização Junho de 2017. Brasília: Departamento Penitenciário Nacional, 2019c.

BRASIL. Ministério da Justiça e da Segurança Pública. Levantamento Nacional de Informações Penitenciárias Junho de 2019. Brasília: Departamento Penitenciário Nacional, 2020b. Disponível em:

https://app.powerbi.com/view?r=eyJrljoiMTVjZDQyODUtN2FjMi00ZjFkLTIhZmItNzQ4Y zYwNGMxZjQzliwidCI6ImViMDkwNDIwLTQONGMtNDNmNy05MWYyLTRiOGRhNmJm ZThIMSJ9 Acesso em 26 fev. 2020.

BRASIL. Ministério da Justiça e da Segurança Pública. Relatório Temático sobre Mulheres Privadas de Liberdade - Junho de 2017. Brasília: Departamento Penitenciário Nacional, 2019d. Disponível em: http://depen.gov.br/DEPEN/depen/sisdepen/infopenmulheres/copy_of_Infopenmulheresjunho2017.pdf Acesso em 26 fev. 2020.

BRASIL. Superior Tribunal de Justiça. Agravo em Recurso Especial $n^{\circ} 1.373 .058$ RS. Relator Ministro Ribeiro Dantas. Julgado em 15 de outubro de 2018.

BRASIL. Superior Tribunal de Justiça. Agravo em Recurso Especial $n^{\circ} 1.429 .409$ RS. Relator Ministro Ribeiro Dantas. Julgado em 29 de março de 2019.

BRASIL. Superior Tribunal de Justiça (5 Turma). Habeas Corpus $n^{0}$ 276.951/RS.

Revista de Direitos Fundamentais \& Democracia, Curitiba, v. 26, n. 1, p. 87-118, jan./abr. 2021. 
Relator Ministro Moura Ribeiro. Brasília, 25 de fevereiro de 2014.

BRASIL. Superior Tribunal de Justiça (5 Turma). Habeas Corpus $n^{\circ}$ 304.325/DF. Relator Ministro Felix Fischer. Brasília, 2 de junho de 2015.

BRASIL. Supremo Tribunal Federal (Pleno). Arguição de Descumprimento de Preceito Fundamental ${ }^{\circ}$ 518. Rel. Min. Edson Fachin. Brasília, 16 de maio de 2018. 2018b.

BRASIL. Supremo Tribunal Federal (Pleno). Medida Cautelar na Arguição de Descumprimento de Preceito Fundamental ${ }^{\circ}$ 347. Rel. Min. Marco Aurélio. Brasília, 9 de setembro de $2015.2015 b$.

CACICEDO, Patrick. O controle judicial da execução penal no Brasil: ambiguidades e contradições de uma relação perversa. Revista Brasileira de Direito Processual Penal, v. 4, n. 1, p. 413-432, jan/abr. 2018.

CACICEDO, Patrick. O princípio da less eligibility, Revista da EMERJ. Rio de Janeiro, v. 18, n. 67, p. 306-316, 2015. Disponível em:

https://www.emerj.tjrj.jus.br/revistaemerj_online/edicoes/revista67/revista67_306.pdf Acesso em: 27 fev. 2020.

CASTILHO, Ela Wiecko Volkmer de. Controle da legalidade na execução penal. Porto Alegre: Sergio Antonio Fabris Editor, 1988.

COMFORT, Megan. A punição além do infrator legal. Discursos Sediciosos: Crime, Direito e Sociedade. Rio de Janeiro, v. 17/19, p. 175-204, 2010.

DISTRITO FEDERAL. Regimento Interno dos Estabelecimentos Penais. Brasília, 1988. Disponível em: https://www.tjdft.jus.br/informacoes/execucoespenais/vep/legislacao/riep.pdf Acesso em 27 fev. 2020.

DISTRITO FEDERAL. Secretaria de Estado de Segurança Pública. Cartilha do Visitante - PFDF. Brasília, 2018. Disponível em: http://www.sesipe.ssp.df.gov.br/wpcontent/uploads/2018/04/Cartilha-do-visitante-PFDF-V2-2017.pdf Acesso em 27 fev. 2020.

DISTRITO FEDERAL. Governo do Distrito Federal. Subsecretaria do Sistema Penitenciário do Distrito Federal. Brasília, 2020. Disponível em: http://www.sesipe.ssp.df.gov.br/ Acesso em: 29 fev. 2020.

DUARTE, Thaís Lemos. Amor em cárcere: relações afetivas no sistema penitenciário do Rio de Janeiro. Dissertação de Mestrado. Programa de Pós-Graduação em Ciências Sociais. Universidade do Estado do Rio de Janeiro, 2015.

EUROPE. Council of Europe. European Prison Rules. Estrasburgo, 2006. Disponível em: https://rm.coe.int/european-prison-rules-978-92-871-5982-3/16806ab9ae Acesso em: 26 fev. 2020.

FERREIRA, Carolina Costa. A atuação das Defensorias Públicas na Execução Penal: em busca de uma práxis criminológica. Direito Público, Brasília, v. 16, n. 89, set/2019, 
p. 9-28.

GODOI, Rafael. Para uma reflexão sobre os efeitos sociais do encarceramento.

Revista Brasileira de Segurança Pública, v. 5, n. 8, p. 138-154, 2011. Disponível em: http://www.forumseguranca.org.br/storage/download//revista_08.pdf Acesso em: 2 mar. 2020.

LIMA, Fernanda da Silva; VERONESE, Josiane Rose Petry. A proteção integral de crianças e adolescentes negros no Brasil: uma abordagem a partir dos instrumentos normativos internacionais de proteção aos direitos humanos. Revista Direitos

Fundamentais e Democracia. Curitiba, vol. 7, n. 7, (jan./jun. 2010), p. 425-439.

MACHADO, Maíra; PINTO, Patrícia Bocardo Batista. A punição na punição na punição: as múltiplas sanções aplicadas em caso de falta grave nas decisões do TJSP. Revista Brasileira de Ciências Criminais, São Paulo, n. 152, p. 117-143, 2019.

MELO, Felipe Athayde Lins de; DAUFEMBACK, Valdirene. Modelo de Gestão para a Política Prisional. Ministério da Justiça. Brasília: Departamento Penitenciário Nacional, 2016. Disponível em: https://www.justica.gov.br/modelo-degestao_documento-final.pdf Acesso em 26 fev. 2020.

PAVARINI, Massimo; GIAMBERARDINO, André. Teoria da Pena e Execução Penal: uma introdução crítica. Rio de Janeiro: Lumen Juris, 2011.

ROIG, Rodrigo. Execução Penal: teoria crítica. São Paulo: Saraiva, 2016.

ONU - ORGANIZAÇÃO DAS NAÇÕES UNIDAS. Regras de Bangkok: Regras das Nações Unidas para o tratamento de mulheres presas e medidas não privativas de liberdade para mulheres infratoras. Brasília: Conselho Nacional de Justiça, 2016. Disponível em: https://www.cnj.jus.br/wp-

content/uploads/2019/09/cd8bc11ffdcbc397c32eecdc40afbb74.pdf Acesso em 26 fev. 2020.

ONU - ORGANIZAÇÃO DAS NAÇÕES UNIDAS. Regras de Mandela: Regras Mínimas das Nações Unidas para o Tratamento dos Presos. Brasília: Conselho Nacional de Justiça, 2016.

PERNAMBUCO. Governo do Estado de Pernambuco. Secretaria Executiva de Ressocialização. Recife, 2020. Disponível em: http://www.seres.pe.gov.br/ Acesso em: 29 fev. 2020.

RIO DE JANEIRO. Governo do Estado do Rio de Janeiro. Secretaria de Estado da Administração Penitenciária. Rio de Janeiro, 2020. Disponível em: http://www.seres.pe.gov.br/ Acesso em: 29 fev. 2020.

SANTA CATARINA. Governo do Estado de Santa Catarina. Secretaria de Estado da Administração Prisional e Penitenciária. Florianópolis, 2020. Disponível em: http://www.sap.sc.gov.br/ Acesso em: 29 fev. 2020.

SHIMIZU, Bruno. A jurisdicionalização perversa na execução penal: reflexão crítica sobre a transformação de uma garantia fundamental em um entrave a mais ao 
exercício de direitos. Revista Brasileira de Ciências Criminais, v. 152, p. 19-64, 2019.

TEIXEIRA, Alessandra; OLIVEIRA, Hilem. Maternidade e encarceramento feminino: o estado da arte das pesquisas no Brasil. BIB, São Paulo, n. 81, p. 25-41, 2016.

TJDFT - Tribunal de Justiça do Distrito Federal e Territórios (1 Turma Criminal).

Agravo em Execução n 20170020128600RAG. Rel. Designada Des. Sandra De Sanctis. Brasília, 24 de agosto de 2017.

TJDFT - Tribunal de Justiça do Distrito Federal e Territórios (2 Turma Criminal).

Agravo em Execução n 20170020211316RAG. Rel. Des. Maria Ivatônia. Brasília, 9 de novembro de 2017.

TJDFT - Tribunal de Justiça do Distrito Federal e Territórios. Vara de Execução Penal. Portaria $n^{\circ} 001$ de 2001. Disponível em:

https://www.tjdft.jus.br/informacoes/execucoes-penais/vep/legislacao/port_01_2001.pdf Acesso em 27 fev. 2020.

TJDFT - Tribunal de Justiça do Distrito Federal e Territórios. Vara de Execução Penal. Portaria $n^{\circ} 08$ de 2016. [Regula a realização de Visitas ordinárias e extraordinárias, bem como de visitas e pesquisas acadêmicas nos estabelecimentos prisionais do DF. Revoga as Portarias n. 001/2001 e 011/2003]. Disponível em:

https://www.tjdft.jus.br/informacoes/execucoes-penais/vep/legislacao Acesso em 27 fev. 2020.

TJDFT - Tribunal de Justiça do Distrito Federal e Territórios. Visitas em Estabelecimentos Penais. Disponível em:

https://www.tjdft.jus.br/informacoes/execucoes-penais/vep/informacoes/visitas Acesso em: 27 fev. 2020.

Recebido em 18/05/2020

Aprovado em 18/04/2021

Received in 18/05/2021

Approved in 18/04/2021 